\title{
LA ACCIÓN PENAL Y LA VÍCTIMA EN EL Derecho CHILENo*
}

["The Criminal Proceedings and the Victim in the Chilean Law"]

\author{
Andrés Bordalí SalamancA ${ }^{* *}$ \\ Universidad Austral de Chile
}

\begin{abstract}
RESUMEN
El presente trabajo analiza la jurisprudencia del Tribunal Constitucional y la doctrina nacional sobre la interpretación $\mathrm{y}$ alcances que han dado al precepto del artículo 83 inciso $2^{\circ} \mathrm{CPol}$., que reconoce igualmente a los ofendidos por delito el ejercicio de la acción penal. El trabajo muestra una posición crítica a los intentos de ver en ese precepto un derecho fundamental a la tutela judicial en beneficio de las víctimas de delito. Se analiza también un análisis comparado sobre la situación de las víctimas y la acción penal en el derecho español e italiano.

\section{Palabras clave}

Acción penal - Derecho a la tutela judicial - Víctimas.
\end{abstract}

\begin{abstract}
This article analyzes the jurisprudence of the Constitutional Court and the Chilean doctrine on the interpretation of article 83, sub-paragraph 2, CPol, and the scope given to said article, which equally grants the exercise of the criminal action to the offended parties. This work shows a critical position regarding the attempts to see in this norm a fundamental right of legal protection in the interest of victims of a certain crime. A comparative analysis regarding the situation of the victims and the legal action in the Spanish and Italian law is also carried out.

KEYwORDs
Criminal proceedings - Right to legal
protection - Victims

\section{KEYWORDS} protection - Victims
\end{abstract}

[RECiBido el 12 y ACEPTADo el 28 de octubre de 2011].

* Este trabajo forma parte y es financiado por el proyecto FondECyT No 1100362 sobre "La acción penal", del que el autor es su investigador responsable.

** Doctor en Derecho, profesor titular de Derecho procesal de la Facultad de Ciencias Jurídicas y Sociales de la Universidad Austral de Chile. Dirección: Campus Isla Teja s/n, Casilla 567, Valdivia, Chile. Correo electrónico: abordali@uach.cl 


\section{INTRODUCCIÓN}

El concepto de acción es uno de aquellos que más tiempo y ocupación ha demandado a los cultivadores del proceso civil, pero hasta un punto tal que ya desde hace bastante tiempo ha sido dejado a un lado por no haber un consenso sobre su significado y, quizá lo más relevante, porque no hay necesidad de tener claridad sobre la naturaleza jurídica del acto de poner en movimiento el proceso por el actor que vaya más allá del aforismo "ne procedat iudex ex officio".

De este modo, más relevante que determinar si estamos frente a un derecho, poder, facultad o potestad, parece ser que lo indispensable de la actividad procesal civil es que los jueces no puedan actuar de oficio en la incoación del proceso y que los afirmados titulares de derechos subjetivos puedan pedir a los tribunales de justicia tutela para los mismos.

Este poder ha sido elevado en muchos ordenamientos jurídicos a la categoría de derecho fundamental, como ocurre en los textos constitucionales español (artículo 24) e italiano (artículo 24), así como parece ser en el chileno (artículo $19 \mathrm{~N}^{\circ} 3$ inciso $1^{\circ}$ de la Constitución Política [en adelante CPol.], según la doctrina constitucional local y la jurisprudencia del Tribunal Constitucional chileno que poco a poco se ha ido consolidando en ese sentido.

Si el reconocimiento de un poder al afirmado titular de un derecho subjetivo para solicitar tutela del mismo a la jurisdicción cuando éste ha sido violado, negado o desconocido por otro sujeto, parece ser esencial al proceso civil, lo que podemos entender como ejercicio de la acción civil, surge el cuestionamiento si ese mismo poder existe y es necesario que exista en el proceso penal. Es decir, así como existe una acción civil para el que afirma una necesidad de amparo para sus derechos, corresponde preguntarse si existe una acción penal en cabeza de los afectados por delito para obtener tutela judicial.

La pregunta es relevante porque aun cuando se pudiera entender que la acción tiene un sentido abstracto como puro poder para poner en movimiento la actividad jurisdiccional, la mayoría de los textos constitucionales así como los planteamientos doctrinales dominantes consideran que sólo puede ejercer la acción quien sea titular o afirme ser titular de un derecho subjetivo y, agregarán otros, un interés legítimo reconocido por el orden jurídico y que puedan obtener tutela vía proceso judicial.

De este modo, cualquiera sea la concepción de la acción y los requisitos para poder ejercerla, parece ser que no es concebible el ejercicio del derecho de acción con total desvinculación de los derechos e intereses materiales por los que se acciona.

La excepción a esta idea la constituye el reconocimiento que en algunos casos realiza el ordenamiento jurídico de una acción popular en que el actor 
no tiene que invocar ninguna posición jurídica subjetiva afectada, como tampoco ninguna necesidad, ventaja o utilidad, sino que simplemente se autoriza a cualquier ciudadano para solicitar a un tribunal que se respete la legalidad vigente.

De esta manera parece ser que, salvo el caso de la acción popular que no entra en los cánones normales del derecho de acción, se tiene un derecho a la tutela judicial o acción no de una manera amplia y abstracta en el sentido de un mero poder reconocido a toda persona de poner en movimiento la actividad jurisdiccional, sino que este derecho se tiene en conexión con posiciones jurídicas subjetivas reconocidas por el derecho material o con la obtención de alguna utilidad legítima en la respuesta judicial. Esto quiere decir que la acción reconocida constitucionalmente nunca puede ejercerse con total abstracción de derechos subjetivos o intereses reconocidos por el derecho material.

Sin embargo, tanto el Tribunal Constitucional español como el chileno han considerado que todas las personas y el ofendido por delito, en el caso español, o bien solo el ofendido por delito, en el caso chileno, tienen un derecho a la acción o a la tutela judicial en materia penal, entendiendo que el proceso penal es apto para brindar tutela a esos derechos e intereses penales.

Se trata de una posición muy aislada en el contexto comparado y en estas páginas intentaré justificar por qué esa jurisprudencia española y chilena no son correctas, pues dan vigencia a un derecho fundamental, el de la tutela judicial, en ámbitos donde no corresponde que rija.

\section{LA ACCión en el Derecho Procesal}

La doctrina de la acción surge en el ámbito del proceso civil ${ }^{1}$ y sólo después se intentó aplicar al proceso penal. Es quizá la construcción del concepto de acción en el campo civil lo que permitió a mediados del siglo XIX en Alemania construir la rama del derecho denominada Derecho procesal desvinculada del Derecho material privado.

Sin embargo, el problema de la doctrina procesal alemana que se forma a mediados del siglo XIX y que luego tiene una fértil acogida a principios del siglo XX en Italia, es que construyó un sinnúmero de teorías que poco o nada tienen que ver en muchos casos con la legislación contenida en los códigos procesales y sin que de las cuales se obtengan muchas veces resultados útiles.

Y en relación al concepto de acción es quizá donde el abuso de la teoría

${ }^{1}$ Véase: De la Oliva, Andrés, Sobre el derecho a la tutela jurisdiccional. La persona ante la Administración de Justicia: Derechos básicos (Barcelona, Bosch, 1980), p. 108. 
ha sido más fuerte. Casi toda la doctrina procesal italiana de la primera mitad del siglo XX se dedicó a construir teorías procesales, recibiendo la acción el principal interés. Giovanni Tarello, ese gran teórico del derecho de Génova, denominó a los procesalistas italianos de esta época, con Chiovenda a la cabeza, como exponentes de un mentalismo conceptual, lo que se explica fundamentalmente en relación a su trabajo sobre la acción. Los escritos de Chiovenda sobre la acción de principios del siglo XX fueron la primera monografía italiana de derecho procesal que tenía por objeto de estudio no ya un instituto disciplinado por la ley positiva, sino un mero concepto jurídico ${ }^{2}$.

No es de extrañar que luego de la tesis de Chiovenda y otros autores sobre la acción, años más tarde surgieran voces que pedían abandonar su estudio, por inútil, como cuando Alcalá-Zamora y Castillo ${ }^{3}$ abogó por organizar sus solemnes funerales.

Pues bien, ante la dificultad de la doctrina procesal de unificar criterios para comprender el concepto de acción civil, se unen luego otros problemas como lo son los de su consideración en el campo procesal penal, como asimismo su reconocimiento a un nivel constitucional.

Uno de los primeros deslindes de nuestra doctrina procesal sobre la acción comprendida constitucional y legalmente, corresponde a un trabajo desarrollado en los años sesenta del siglo pasado por los autores Alex Avsolomovich, Germán Lührs y Ernesto Noguera ${ }^{4}$. Pero luego la doctrina constitucional poco o nada ha profundizado sobre el sentido y significado de un derecho constitucional de acción. Humberto Nogueira ha sido de los pocos que ha tratado sobre la existencia de un derecho de acción entendido como derecho a obtener tutela judicial ${ }^{5}$, aunque sin un desarrollo más incisivo sobre el significado y contenidos concretos de este derecho en sede procesal. A su vez, siguiendo a una doctrina y jurisprudencia españolas muy difundidas, Nogueira incluye el derecho de acceso a los tribunales dentro de las exigencias de un debido proceso, cuando se trata de dos tipos de derechos diferentes, aunque en evidente relación. Esa misma confusión entre derecho de acción

${ }^{2}$ Cfr. Tarello, Giovanni, Dottrine del processo civile. Studi storici sulla formazione del diritto processuale civile (Bolonia, Il Mulino, 1989), p. 243.

${ }^{3}$ Véase: Alcalá-Zamora y Castillo, Niceto, Estudios de teoría e historia del proceso (1945-1972) (México, D.F., UNAM, 1992), I, p. 323.

${ }^{4}$ Véase: Avsolomovich, Alex - LüHrs, Germán - Noguera, Ernesto, Nociones de Derecho procesal (Santiago, Editorial Jurídica de Chile, 1965), pp. 26 ss.

${ }^{5}$ Véase: Nogueira, Humberto, La constitucionalización del proceso: El acceso a la jurisdicción, tutela judicial efectiva o debido proceso, en FERRADA, Juan Carlos (coordinador), La constitucionalización del Derecho chileno (Santiago, Editorial Jurídica de Chile, 2003), passim. 
y derecho al debido proceso la sostiene nuestro Tribunal Constitucional en múltiples fallos ${ }^{6}$.

Con un carácter general debe entenderse que nuestro derecho de acción o derecho a la tutela judicial se encuentra reconocido en el artículo $19 \mathrm{~N}^{\circ} 3$ inciso $1^{\circ} \mathrm{CPol}$. Con un carácter específico en materia administrativa puede entenderse reconocido en el artículo 38 inciso $2^{\circ} \mathrm{CPol}$.

Con el derecho a la tutela judicial se permite solicitar tutela jurisdiccional para los derechos subjetivos de las personas.

Podría sostenerse que el derecho a la tutela judicial también permite la tutela jurisdiccional de intereses legítimos. La incorporación de los intereses legítimos en nuestro derecho a la tutela judicial puede justificarse en orden a dos tipos de consideraciones. En primer lugar, por una influencia de las constituciones española e italiana, las que expresan en un mismo artículo 24 el derecho a solicitar tutela judicial para derechos e intereses legítimos. Esos intereses legítimos existen especialmente respecto de actos o actuaciones de la Administración del Estado. Si en Chile se habla de tutela judicial, inmediatamente se lo asocia a estos derechos reconocidos y latamente desarrollados por la doctrina y jurisprudencia tanto en España como en Italia, donde se da tutela judicial tanto para derechos subjetivos como intereses legítimos.

Por otra parte, el derecho de acción o a la tutela judicial puede ser entendido como un derecho a solicitar tutela de los tribunales para aquellas posiciones jurídicas subjetivas que invoquen los individuos y que reconoce el orden jurídico. Un sector de la doctrina nacional señala que además de los derechos subjetivos existen, como posiciones jurídicas subjetivas, los denominados intereses ${ }^{7}$ o bien intereses legítimos ${ }^{8}$. La conclusión lógica que puede derivarse es que el constituyente tuvo la intención de que las personas deben tener siempre reconocida la posibilidad de obtener tutela jurisdiccional para sus posiciones jurídicas subjetivas de que son titulares, sean derechos subjetivos u otras, como los intereses. No estaría acorde con un Estado que está al servicio de la persona humana (artículo $1^{\circ} \mathrm{CPol}$.), si existiesen determinadas posiciones jurídicas subjetivas que no fuesen

${ }^{6}$ Puede verse un análisis crítico de la concepción del Tribunal Constitucional sobre el derecho a la tutela judicial en BORDALÍ, Andrés, Análisis critico de la jurisprudencia del Tribunal Constitucional sobre el derecho a la tutela judicial, en Revista de Chilena de Derecho, 38 (2011) 2, pp. 311 a 337.

${ }^{7}$ Véase: Diez, José Luis, El daño extracontractual. Jurisprudencia y doctrina (Santiago, Editorial Jurídica de Chile, 1997), p. 25.

${ }^{8}$ Véase: CoRdero, Eduardo, La legitimación activa en el proceso contencioso administrativo, en FERRADA, Juan Carlos (coordinador), La justicia administrativa (Santiago, LexisNexis, 2005), pp. 394 ss.; Romero, Alejandro, Curso de Derecho procesal civil. La acción y la protección de los derechos (Santiago, Editorial Jurídica de Chile, 2006), p. 13; Nogueira, Humberto, cit. (n. 5), p. 174. 
estrictamente derechos subjetivos, como los intereses legítimos, pero no se pudiese pedir tutela al Estado para ellos. Si existen tales intereses legítimos en nuestro ordenamiento jurídico, lo que por cierto puede ser puesto en discusión, el derecho a la tutela judicial debe ser el mecanismo por el cual se puede exigir su amparo.

Como sea, la acción en cuanto derecho constitucional a la tutela judicial se ejercita para pedir tutela a una posición jurídica subjetiva reconocida por el ordenamiento jurídico, sea ésta solo un derecho subjetivo o bien, derecho subjetivo e interés legítimo. No existe el derecho de acción por un puro deseo que se desarrolle la actividad jurisdiccional. Esto quiere decir que en nuestro ordenamiento jurídico la acción no puede nunca ser concebida con abstracción de posiciones jurídicas subjetivas de los individuos.

Esta conexión entre acción y derechos e intereses materiales se hace por intermedio del concepto de legitimación, específicamente la ordinaria, anclada en derechos e intereses individuales. A veces se entiende que la legitimación es un elemento de la acción ${ }^{9}$, donde la vinculación del actor con los derechos e intereses por los que se pide tutela se refiere a una cuestión de fondo. Para poder accionar se debe ser titular de los derechos e intereses por los que se pide tutela o, dicho de otro modo, para poder accionar se debe estar legitimado activamente, lo que quiere decir que se debe ser titular de los derechos o intereses legítimos en cuestión.

Por el contrario, para otro sector de la doctrina la vinculación del actor con los derechos e intereses por los que pide tutela tiene una doble vertiente: una procesal al inicio del proceso y que dice relación con instauración del proceso. La legitimación es aquí un presupuesto procesal que de existir o no determinará la obligación del juez de seguir hacia adelante el proceso hasta la sentencia definitiva. Y como se trata de un concepto procesal, sólo importa que se afirme inicialmente la titularidad de ese derecho o interés, no que se sea realmente titular de ellos. En segundo lugar, si el actor es o no titular del derecho o interés legítimo por el que accionó, ello sólo se sabrá al final del proceso con la sentencia definitiva que se pronuncia sobre el fondo de la pretensión ${ }^{10}$.

En mi concepto, la legitimación es un concepto de carácter procesal que debe ser controlada a inicios del proceso. La titularidad de los derechos o intereses invocados solo se sabrá con la sentencia definitiva, pero habrá de hablarse en ese caso de titularidad de los mismos, sin que sea necesario referirse a esos titulares como legitimados activos.

${ }^{9}$ Véase: Romero, Alejandro, cit. (n. 8), pp. 23 ss.

${ }^{10}$ Véase: Montero Aroca, Juan, La legitimación en el proceso civil (Intento de aclarar un concepto que resulta más confuso cuanto más se escribe sobre él) (Madrid, Civitas, 1994), p. 93. 
Para un sector de la doctrina procesal, además de la exigencia de legitimación, sea que se la considere como elemento material o bien procesal, se exige a quien acciona que exprese un interés en obtener una respuesta jurisdiccional que se relaciona con una necesidad de obtener tutela jurisdiccional derivada de la prohibición de autotutela y monopolio estatal de la tutela judicial. Existe ese interés cuando el sujeto ya no puede lograr por si mismo lo que pretende judicialmente. Se habla así en países como Italia de la necesidad que exista en cabeza del actor de un interés en accionar ${ }^{11}$, interés que se desvincula de los derechos e intereses materiales reconocidos previamente por el ordenamiento positivo $^{12}$ y por los que se pide tutela.

Sin embargo, la exigencia de un interés procesal para poder accionar, como elemento separado de los derechos e intereses por los que se pide tutela y de la acción misma, ha sido puesta en duda por un sector de la doctrina ${ }^{13}$. Existirán derechos subjetivos e intereses legítimos sustanciales, de un lado, y, luego, un poder de acción para pedir tutela para ellos en caso de que lo necesiten. La acción comprende naturalmente ese interés; no es necesario -se dirá- comprenderlo como algo separado.

En resumen, si bien no aparece razonable entender a la acción como un derecho a obtener una sentencia favorable a la tutela de los derechos o intereses legítimos del actor, porque las contingencias inherentes al proceso judicial impiden asegurar siempre y en todo lugar una respuesta judicial positiva aun a quien tenga un derecho o interés a su favor, tampoco parece razonable entender que ella consiste en un puro derecho a poner en movimiento la maquinaria judicial; un puro poder de denuncia que significa la consideración de máxima abstracción de la acción.

La acción, por el contrario, y como se la reconoce en la mayoría de los textos constitucionales (Chile, España e Italia) sólo ampara con la actividad judicial a quien afirme que tiene una determinada posición jurídica subjetiva necesitada de tutela estatal; no a cualquier persona.

La acción es más o menos abstracta en el sentido que no garantiza una sentencia favorable a la pretensión deducida, pero tampoco puede consistir en un derecho para cualquier persona de activar la maquinaria judicial con total abstracción de una específica necesidad de tutela de situaciones jurídicas subjetivas reconocidas por el ordenamiento jurídico.

${ }^{11}$ Véase: Calamandrei, Piero, Derecho procesal civil (México, D. F., Editorial Pedagógica Iberoamericana, 1996), p. 53; MANDrioli, Crisanto, Corso di Diritto processuale civile (Turín, Giappichelli, 2000), p. 44.

${ }^{12}$ Véase: Liebman, Enrico Tulio, L'azione nella teoria del processo civile, en Rivista di diritto e procedura civile, año IV (1950), p. 58.

${ }^{13}$ Véase: Ricci, Gian Franco, Principi di diritto processuale generale (Torino, Giappichelli, 2001), p. 109. 
Si el derecho de acción reconocido en la Constitución es un poder para pedir tutela judicial para derechos e intereses que se afirman como propios, la consecuencia lógica que se deduce es que el legislador debe crear los instrumentos procesales en las leyes de procedimiento para que las personas puedan demandar el amparo para esos derechos e intereses. Si no reconoce ese derecho de demanda o lo dificulta o impide su ejercicio más allá de lo razonable, lo hará de un modo contrario a la Constitución.

De lo razonado, cabe concluir que el derecho de acción solo tiene operatividad en aquellos campos jurídicos donde las personas tengan derechos e intereses materiales reconocidos por el ordenamiento jurídico y donde el proceso judicial sea apto para tutelarlos, lo que se dará en el campo civil, laboral y administrativo y en algunas hipótesis constitucionales, especialmente en el proceso constitucional de las libertades. El proceso penal parece quedar fuera de la órbita del derecho de acción, como pasaré a revisar a continuación.

\section{APLiCACión DEL CONCEPTO DE ACCión EN EL PROCESO CIVIL Y EN EL PENAL}

Existe hasta el día de hoy discusión si las categorías e instituciones que la doctrina procesal alemana y luego italiana, desde mediados del siglo XIX, construyeron para el proceso civil, pueden ser aplicadas sin más al proceso penal. Parte de la doctrina procesal penal de derecho continental de mediados del siglo XX, para construir seguramente una imagen de cientificidad como la que se predicaba del proceso civil, recurrió a muchos conceptos propios del proceso civil, aunque de manera no siempre muy reflexiva ${ }^{14}$.

En la base de una homologación del proceso civil y del penal está una concepción unitaria de la función judicial. La jurisdicción tendría por función la realización del derecho objetivo. Mediante la acción y el proceso civil y penal se realiza el ordenamiento jurídico. Se aplican por tanto al proceso civil y al penal las mismas categorías, conceptos y principios. Se trataría de tan solo un Derecho Procesal.

Carnelutti, si bien no suscribió una concepción objetiva de la función judicial, como realización del Derecho objetivo, sí propuso una noción integral de acción, aplicable tanto al campo civil como penal ${ }^{15}$.

En Chile tanto un sector de la doctrina como alguna jurisprudencia del Tribunal Constitucional han intentado construir una noción de acción aplicable tanto al proceso civil como al penal. Así, el ex fiscal nacional del

${ }^{14}$ Véase: Ricci, Gian Franco, cit. (n. 13), p. 135.

${ }^{15}$ Cfr. Carnelutti, Francesco, Saggio di una teoria integrale dell azione, en Rivista di Diritto Processuale, 1 (1946), Parte I, pp. 11 ss. 
Ministerio Público, don Guillermo Piedrabuena, ha sostenido que la reforma constitucional de 1997 consagró (en el actual artículo 83 inciso $2^{\circ}$ ) una especie de derecho constitucional autónomo a la pretensión, que no es sino el reconocimiento del derecho a la tutela judicial efectiva de los ofendidos por el delito. Este derecho a la tutela judicial efectiva de la víctima, sostiene Piedrabuena, comprende la facultad de deducir en juicio una acción o pretensión penal o civil, en su caso, en contra del supuesto responsable del ilícito penal, así como el deber de los órganos jurisdiccionales de resolver la pretensión formulada, entre otros aspectos. Tienen las víctimas de delito, en definitiva, un derecho a activar el proceso, interponiendo la correspondiente querell $\mathrm{a}^{16}$.

En un sentido similar se pronuncia el voto de mayoría de la sentencia del Tribunal Constitucional de fecha 19 de agosto de 2008, rol $\mathrm{N}^{\circ} 815$ 07, redactada en ese entonces por el Ministro Juan Colombo Campbell. La referida sentencia sostiene reiteradamente que las víctimas de delito tienen un derecho a la tutela judicial. Así en el considerando $6^{\circ}$ señala que es necesario destacar que la Constitución reconoce expresamente el derecho a la acción al ofendido, el que surge como una garantía trascendente para compensar a la víctima de la prohibición y eventual sanción a la autotutela de sus derechos. Agrega este considerando que el ejercicio de la acción penal, forma ordinaria de impulsar la apertura y formación del proceso, continúa siendo el presupuesto primario de su iniciación y, como tal, la primera fase para que éste se tramite legalmente como lo exige la Constitución, lo que debe producir como su efecto natural la apertura del mismo e, incorporándose a él, tiene fundamento constitucional directo, pues constituye un elemento esencial y necesario para que el proceso exista, aun antes de ser calificado, como racional y justo.

Sostiene luego la referida sentencia en su considerando $12^{\circ}$, que el entender la facultad del Ministerio Público de formalizar la investigación como una alternativa discrecional, en la cual no se puede interferir y de la que pueda derivar la decisión de no investigar y eventualmente archivar, aun cuando el afectado por el delito ha manifestado su voluntad de proseguir la persecución penal mediante la interposición de una querella, como ocurre en el casi sub lite, implica un acto de un órgano del Estado que produce como resultado evidente la negación de la tutela de los intereses penales de la víctima, la privación del derecho a la investigación del hecho delictivo y la imposibilidad de acceder a la jurisdicción, para que ésta resuelva el conflicto penal que la afecta, como lo ordena el artículo $7^{\circ} \mathrm{CPol}$.

${ }^{16}$ Cfr. Piedrabuena, Guillermo, La Constitución y los derechos de la victima en el nuevo proceso penal chileno, en La victima y el testigo en la reforma procesal penal (Santiago, Ministerio Público - Editorial Fallos del Mes, 2003), p. 33. 
Continúa este considerando señalando que al ser la tutela judicial efectiva un derecho fundamental, es la persona titular de dicho derecho violentado la que debe disponer del mismo a la hora de resolver si acude o no a la justicia, teniendo presente que el ejercicio y la titularidad de sus derechos se encuentran dentro de la órbita de decisión del ser humano, coto vedado al poder público al estar dentro del marco de lo íntimo e individual, sin que el Estado pueda realizar injerencias dentro de dichos ámbitos. Es por ello que cualquier concepción que prescinda del interés de la víctima, como parte primordial del proceso penal, debe considerarse incompatible con la Constitución.

Luego sostiene esta sentencia en su considerando $14^{\circ}$ que la querella es reconocida constitucionalmente en el artículo $83 \mathrm{CPol}$. Esto quiere decir que el juez accionado por una querella, puede declararla inadmisible o admisible. En este último caso, se produce la apertura del proceso penal, formándose una relación procesal simple, que continúa con su remisión al Ministerio Público para que éste realice la investigación de los hechos denunciados como delito.

En forma muy categórica, otra sentencia del Tribunal Constitucional, la de fecha 28 de enero de 2010, rol N 1535-09, expresa que la querella, el ejercicio de la acción y todas las a actuaciones de la víctima dentro del proceso han de ser entendidas como manifestaciones del legítimo ejercicio de dicho derecho al proceso, por lo que el mismo no puede ser desconocido, ni menos cercenado por el poder estatal (considerando $17^{\circ}$ ). Luego agregará que el derecho al ejercicio de la acción penal se encuentra consagrado de forma expresa y categórica por la Constitución (considerando $25^{\circ}$ ).

Como se puede observar, para estos fallos del Tribunal Constitucional, la acción entendida como derecho a la tutela judicial, tiene una proyección penal y opera de una manera similar a como lo hace en materia civil.

A diferencia de esta doctrina y jurisprudencia que iguala acción civil y penal, la doctrina comparada tiende a separarlas. En la base de un proceso civil está un derecho o poder del titular de un derecho o interés de carácter material, quien es soberano para disponer procesalmente de ellos, demandando o permaneciendo inactivo. El juez que actúa sin demanda usurpa poderes ajenos. La acción solo compete a la parte que es titular, o afirma ser titular, de un derecho o interés ${ }^{17}$.

Dejando de lado una concepción unitaria de la acción, alguna doctrina comienza a concebir la acción penal como categoría intermedia entre un poder y un deber, en el sentido que es tarea funcional del Estado proveer a la realización de la pretensión punitiva que nace del delito ${ }^{18}$. Por otra parte,

${ }^{17}$ Véase: Cordero, Franco, Procedura penale ( $8^{a}$ edición, Milano, Giuffrè, 2066), p. 399.

${ }^{18}$ Véase: BENE, Teresa, La dogmatica dell 'azione penale. Influenze civilistiche ed errori di metodo (Napoli, Jovene editore, 1997), p. 99. 
la acción penal comienza a ser entendida como el acto (demanda) que activa el procedimiento penal, pero también es entendida como el procedimiento mismo (actividad) que realiza el derecho penal.

Lo mismo sucede con la evolución de la función judicial. Hoy en día la doctrina pone especial énfasis en la función del proceso civil como tutela de derechos de las personas ${ }^{19}$, antes que una realización abstracta del derecho objetivo, que aun puede ser entendida como la función primordial del proceso penal.

Todo lo anterior indica que no es apropiado utilizar conceptos típicamente civiles en el campo procesal penal. La situación de la acción parece ser paradigmática. Si entendemos que el derecho de acción permite ocurrir ante un tribunal de justicia y obtener una respuesta judicial según derecho a quien necesita tutela jurisdiccional para un derecho subjetivo o interés legítimo necesitado de tal amparo, parece ser que en el campo penal no puede haber un derecho de acción para los ofendidos por delito, toda vez que éstos no pueden obtener vía proceso penal tutela para ningún derecho subjetivo ni interés legítimo lesionado. He aquí a mi juicio la diferencia esencial entre la acción civil y la penal. En la primera subyacen situaciones jurídicas subjetivas reconocidas por el ordenamiento jurídico material que pueden ser amparados por el proceso judicial; en el segundo parece que no existen tales situaciones subjetivas. Sin embargo, existe alguna doctrina y jurisprudencia que afirman que esos derechos e intereses también existen en el derecho penal y que el proceso penal puede tutelarlos.

\section{LOS DERECHOS E INTERESES PENALES} Y SU TUTELA JURISDICCIONAL

Nuestro Tribunal Constitucional se inclina por la tesis que los ofendidos por delito son afectados en derechos e intereses de carácter penal y que el proceso penal es la vía para tutelarlos. Así en el considerando $6^{\circ}$ de la sentencia rol N ${ }^{\circ} 815-07$, se señala que es necesario destacar que la Constitución reconoce expresamente el derecho a la acción al ofendido, el que surge como una garantía trascendente para compensar a la víctima de la prohibición y eventual sanción a la autotutela de sus derechos. Luego, en el considerando $12^{\circ}$, sostiene que el entender la facultad del Ministerio Público de formalizar la investigación como una alternativa discrecional, en la cual no se puede interferir y de la que pueda derivar la decisión de no investigar y eventualmente archivar, aun cuando el afectado por el delito ha manifestado su voluntad

\footnotetext{
${ }^{19}$ Véase: MARINONI, Luiz Guilherme, Derecho fundamental a la tutela jurisdiccional efectiva (Lima, Palestra, 2007), pp. 47 ss.
} 
de proseguir la persecución penal mediante la interposición de una querella, como ocurre en el casi sub lite, implica un acto de un órgano del Estado que produce como resultado evidente la negación de la tutela de los intereses penales de la víctima.

En la sentencia del Tribunal Constitucional rol N ${ }^{\circ} 1404-09$, en su considerando $29^{\circ}$, se expresa que el afectado puede ejercer en el procedimiento penal un conjunto de prerrogativas tendientes a obtener la tutela jurisdiccional efectiva de sus intereses.

La víctima de delito o el ofendido, según el Tribunal Constitucional, tiene derecho a obtener tutela judicial para sus derechos e intereses. Se trataría, ciertamente, de derechos e intereses penales. No se está refiriendo a los derechos e intereses civiles del ofendido por delito.

Pero, ¿se puede decir que las personas tienen derechos e intereses de tipo penal que pueden ser tutelados por el proceso penal? A mi entender no existen los derechos o intereses de contenido penal. Cosa distinta es que existan en torno al proceso penal otros tipos de derechos o intereses, de tipo civil o bien constitucional. Así, la Corte Europea de Derechos Humanos ha dicho que en el proceso penal tanto las víctimas como los testigos tienen un conjunto de derechos fundamentales que miran a proteger la vida, libertad, seguridad, vida privada y familiar. Tales derechos, ha dicho esta Corte, deben ser protegidos por el sistema procesal penal de modo que no sean puestos indebidamente en peligro ${ }^{20}$. A tales derechos deben agregarse los de tipo patrimonial para recuperar las especies del delito o bien para obtener una reparación por los daños causados.

Hay que despejar aquí algunas cuestiones que pueden inducir a confusión. Tras todo delito puede haber una vulneración de derechos. Muchos delitos comportan la violación de derechos fundamentales, como el derecho a la vida, a la integridad física y psíquica, un genérico derecho de libertad, derecho de propiedad, derecho al honor, derecho a la inviolabilidad del domicilio, etc. Entonces, cuando se lleva a un imputado a juicio penal, tras ello existe una violación de derechos, sean de carácter legal pero en muchos casos se trata de verdaderos derechos constitucionales. La pregunta que corresponde formularse es si el proceso penal y la sentencia penal condenatoria, son la vía para dar tutela a esos derechos individuales de la víctima. La respuesta es no.

Las vías procesales que permiten dar tutela a esos derechos legales o constitucionales lesionados por el responsable del delito son las del procedimiento civil restitutorio de las especies hurtadas, robadas o estafadas, la indemnización del daño producido, tanto material como moral, la nulidad de las convenciones y la cancelación de las inscripciones en los registros co-

${ }^{20}$ Sentencia de fecha 26 de marzo de 1996, causa “Doorson v/s Países Bajos”. 
rrespondientes, la reposición de los deslindes al estado anterior, en los delitos de destrucción o alteración de términos o límites de propiedades públicas o particulares, etcétera. ${ }^{21}$. Como se puede ver, estamos frente a pretensiones civiles no penales.

En nuestro sistema procesal, el ofendido por el delito puede ejercer esas pretensiones civiles opcionalmente dentro del procedimiento penal o bien ante el juez civil competente. La restitución de las especies solo puede llevarse a cabo dentro del procedimiento penal. A ello debe agregarse la posibilidad de lograr acuerdos reparatorios entre la víctima del delito y el imputado.

Por otra parte, deben considerarse las vías de protección a la víctima y a su familia que debe brindar el Ministerio Público por amenazas de parte del ofendido o su entorno. Esa es otra forma de dar amparo a la víctima de delito al margen de un proceso penal.

Sin embargo, puede plantearse si un modo de dar protección o amparo a la víctima en sus derechos sea con la dictación de una sentencia condenatoria a una pena privativa de libertad del acusado por delito. Esto es especialmente relevante cuando la víctima ha sufrido atentados contra su vida, integridad física o libertad sexual, por ejemplo. Es decir, se puede pensar que en estos casos la pena privativa de libertad impuesta a través de un proceso penal tiene por fin tutelar determinados derechos de la víctima. Ésta vería tutelado su derecho a la vida, integridad física o libertad sexual con la condena del acusado a una pena privativa de libertad. Estando el acusado encerrado en un recinto carcelario no podrá atentar, al menos por un tiempo, contra los derechos de la víctima ¿Puede tener ese fin la pena?

No es ésta la sede de plantear los fines de la pena, que excede con mucho las finalidades de esta investigación. Sin embargo, se puede señalar que la doctrina generalmente destaca en la pena una naturaleza esencialmente de carácter pública, orientada a la colectividad y al infractor de la norma, con fines esencialmente preventivos ${ }^{22}$. Tradicionalmente los fines de la pena han sido la retribución de un mal al responsable de delito, o bien, evolutivamente, lograr su resocialización, a lo que se puede agregar un fin educativo al expresar el acto de imposición de la pena un mensaje moral para el responsable. El autor de delito entiende o aprende con la imposición de la pena que se encuentra en un error ${ }^{23}$.

${ }^{21}$ Véase: Horvitz, María Inés - López, Julián, Derecho procesal penal chileno. Principios, sujetos procesales, medidas cautelares, etapa de investigación (Santiago, Editorial Jurídica de Chile, 2007), I, p. 611.

${ }^{22}$ Véase: Horvitz, María Inés - López, Julián, cit. (n. 21), p. 601.

${ }^{23}$ Véase: VAlenZuela, Jonatan, La pena como penitencia secular. Apuntes sobre el sentido de la ejecución de la pena, en Revista de Derecho de la Universidad Austral de Chile, 23 (julio 2010) 1, p. 259. 
Como sea, se puede decir que la pena, especialmente cuando es de privación de libertad, no busca una protección directa de la víctima en sus derechos $^{24}$.

Pero un sector de la doctrina no descarta que las víctimas de delito tengan verdaderos intereses de tipo penal que logran su tutela a través del proceso penal. Así se sostiene en ocasiones que la víctima de delito tiene un interés de tipo penal que consiste en que se establezca la verdad, para lo cual puede ejercitar los derechos y las facultades que confiere la ley procesal penal.

En otras ocasiones se dice que el proceso penal tiene un fin terapéutico en relación con los sentimientos y experiencias que siente la víctima, que son generalmente de miedo, sospecha, aislamiento, incerteza, sentido de culpa y depresión, especialmente cuando se trata de crímenes graves ${ }^{25}$. Permitir a las víctimas ser parte activa del procedimiento penal puede ayudarlas a ganar autoestima y reducir su sentimiento de impotencia.

Garantizándoles a las víctimas de delito que se desarrolle un proceso penal, permitiéndoles que puedan hablar ante el tribunal, puede ello tener, se dice, un efecto catártico ${ }^{26}$.

En otras ocasiones se dice que el interés de la víctima consiste en obtener justicia, identificándose al responsable y luego condenándole ${ }^{27}$. El deseo de obtener justicia por los ofendidos por delito no es otra cosa que el deseo de lograr que se condene a la persona considerada culpable ${ }^{28}$.

De acuerdo con lo anterior, las víctimas de delito parecen tener dos tipos de intereses en relación con el proceso penal. En primer lugar, el desarrollo del proceso penal les puede ayudar a curar las heridas que el delito que les ha causado, ganando confianza y autoestima. Hablaremos de un interés en la obtención de la verdad y un interés a la reparación. El proceso penal

${ }^{24}$ Cosa distinta es que el proceso penal tenga fines distintos a la aplicación de una pena, fines que pueden corresponder a una compensación o reparación del mal causado. Véase: KUNSEMÜLLER, Carlos, Las actuales relaciones entre derecho penal sustantivo y derecho penal adjetivo, en Romero, Alejandro (coordinador), Estudios de derecho en homenaje a Raúl Tavolari Oliveros (Santiago, LexisNexis, 2007), p. 330. Sin embargo, no está del todo claro que en estos casos estemos frente a un proceso que realiza el Derecho penal. La idea de reparar a la víctima hace que las fronteras entre el Derecho civil y el penal se tornen poco nítidas. Véase: LüDERSSEN, Klaus, Il declino del diritto penale (Milano, Giuffrè, 2005), pp. 33 ss.

${ }^{25}$ Véase: Floridia, Pietro, Diritti processuali o servizi a favore della vittima? en BIsi, Roberta - Faccioli, Patrizia, Con gli occhi della vittima. Approccio interdisciplinare alla vittimologia (Milano, Franco Angeli, 1996), p. 27.

${ }^{26}$ Véase: Floridia, Pietro, cit. (n. 25), p. 29.

${ }^{27}$ Véase: Pagliaro, Antonio, Tutela della vittima nel sistema penale delle garanzie en Rivista Italiana di Diritto e Procedura Penale, fasc. 1 (enero-marzo 2010), p. 48.

${ }^{28}$ Véase: Caianiello, Michele, Poteri dei privati nell 'esercizio dell 'azione penale (Torino, Giappichelli, 2003), p. 140. 
tiene aquí un efecto catártico y terapéutico. Pero el otro interés que suelen tener las víctimas en el proceso penal es lograr que le sea aplicada una pena al responsable del delito. En este caso no le sirve tanto el proceso penal y la posibilidad de ser escuchado en él, sino lo que busca la víctima es que se sancione al acusado, aplicándosele una pena.

Se trata en todo caso de intereses que el ordenamiento jurídico no reconoce de manera expresa y por lo tanto es discutible que ellos estén en la base material del proceso penal. No es lo mismo sostener que se acciona para pedir tutela para el derecho de propiedad, un derecho que nace de un contrato o un derecho que reconoce la ley laboral, como ocurre en el campo civil y laboral, que accionar para que se conozca la verdad o se aplique una pena al acusado. No se trata de derechos e intereses de la misma entidad.

Ahora bien, aun cuando se pueda reconocer la existencia de ciertos intereses penales de las víctimas de delito que pueden lograr su tutela ya con la mera realización del proceso penal o bien con la condena del acusado, ello no debería llevar a entender que las víctimas tienen un derecho fundamental a la tutela judicial que les permitiría llevar, cuando ellos lo deseen, a una persona a juicio penal y buscar su condena.

Esos intereses de las víctimas deben balancearse con un conjunto de intereses públicos referidos a la racionalización del sistema penal, que implican entre otras cosas que quienes acusen penalmente a otros sean considerados sujetos independientes, para evitar arbitrariedades ${ }^{29} \mathrm{y}$ condenas desproporcionadas $^{30}$. Además se busca uniformidad en los criterios de acusación penal, lo que solo puede garantizar un órgano acusador público ${ }^{31}$.

Por otra parte, esos intereses de la víctima consistentes en conocer la verdad o en obtener justicia no son otra cosa, en la mayoría de los casos, que el deseo de atribuir un mal al responsable del delito, interés retributivo individual que no tiene cabida en el ordenamiento jurídico sustancial. A lo más podría entenderse que la víctima tiene un interés que es reflejo del interés público penal que custodia el Ministerio Público.

En efecto, la tutela estrictamente penal en los sistemas regidos por el principio de oficialidad es de tipo objetiva, donde la persona ofendida por el delito obtiene una tutela no directamente, sino como reflejo de una protección de los intereses públicos. Sin embargo, esa tutela objetiva no obsta a que en el procedimiento penal el ofendido tenga reconocido algunos derechos como veremos más adelante.

${ }^{29}$ Véase: SCALfati, Adolfo, La fisionomia mutevole della persona offesa nel procedimiento penale di pace, en Diritto penale e processo, 8 (octubre 2002), p. 1.189.

${ }^{30}$ Véase: Floridia, Pietro, cit. (n. 25), p. 31.

${ }^{31}$ Véase: DíEz- Picazo, Luis María, El poder de acusar. Ministerio Fiscal y constitucionalismo (Barcelona, Ariel, 2000), p. 111. 
De acuerdo con lo dicho, las víctimas de delito no tienen un derecho a la tutela judicial en los mismos términos de una persona que ha visto afectados sus derechos subjetivos reconocidos por las leyes civiles, laborales, administrativas y, obviamente, los derechos constitucionales.

Todo esto puede ser explicado con el siguiente ejemplo. Pensemos en una tutela del derecho a la vida. Si una persona sufre amenazas a su vida o integridad física, puede interponer un recurso de protección para que se le otorgue amparo, pidiendo custodia policial. El tribunal competente determinará si la amenaza es seria y grave y si corresponde acceder a la pretensión del actor. He aquí un claro ejercicio del derecho a la tutela judicial.

Fuera del ejercicio del derecho a la tutela judicial, el amenazado o el que ha sufrido agresiones podrá concurrir al Ministerio Público haciendo una denuncia por delito y solicitar de este organismo alguna medida de protección. Y fuera también del derecho a la tutela judicial podrá participar activamente de la investigación penal, ejerciendo los derechos que le confiere la ley, incluido el derecho de presentar querella y acusar, entre otros derechos.

El Estado no puede satisfacer el interés individual de la víctima a que se sancione al responsable de delito. Por ello no puede reconocerle un derecho a la tutela judicial para que satisfaga ese interés.

Ahora bien, si el proceso penal tiene un efecto sanador y catártico para la víctima, entonces el sistema penal puede ayudarla en muchos sentidos. Así, el Estado deberá tratar a las víctimas con la máxima consideración y haciéndola partícipe del reproche social que implica el delito que ha sufrido. Para ello es esencial que la víctima partícipe del procedimiento penal, siendo un deber para el sistema judicial notificar todas las decisiones importantes referidas al caso. De vital importancia es que tanto las autoridades del Ministerio Público como las judiciales puedan escucharla. Asimismo, una rápida solución del caso también puede ayudarla ${ }^{32}$. Pero nuevamente en todo ello no habrá de verse un derecho a la tutela judicial.

\section{LA ACCIÓN EN LOS CÓdigOS PROCESALES PENALES}

En el derecho procesal penal chileno siempre se ha hablado y reconocido el término acción penal. Y ese reconocimiento tiene hoy en día partida doble en nuestro derecho ya que tanto la Constitución (artículo 83) como el Código Procesal Penal (título $3^{\circ}$ y otras disposiciones) se refieren a la acción penal. Y es natural que se hable de acción penal porque el proceso penal, como se vio, ha sido tradicionalmente construido tomando como base las construcciones lingüísticas provenientes del proceso civil.

${ }^{32}$ Véase: Floridia, Pietro, cit. (n. 25), p. 37. 
Sin embargo, así como en materia civil el concepto de acción es problemático, en materia procesal penal esa dificultad se multiplica exponencialmente. Los problemas son de varios tipos. En primer lugar, hay que concordar que en el proceso penal existe normalmente la figura del Ministerio Público, quien ejerce la acción penal pública. Junto a él a veces se reconoce la figura del querellante particular e inclusive el actor popular.

En el caso del Ministerio Público surge la duda de si se entiende que ejerce la acción como manifestación de un derecho a la tutela judicial. ¿Ejerce un derecho el Ministerio Público? Este tema se entronca en el más vasto referido a si los órganos públicos actúan con base a derechos o bien en virtud de deberes u obligaciones. Es que en el proceso penal predomina un interés público y con él el denominado principio de oficialidad, que quiere decir que la sociedad está especialmente interesada en el descubrimiento de los delitos y el castigo de sus autores. De aquí que se discuta si la acción penal deba ser concebida como un derecho, quedando quizá mejor expresada en la idea de un deber ${ }^{33}$.

Luego está el problema de la propia estructura del enjuiciamiento criminal que en el caso chileno tiene una etapa de investigación no jurisdiccional a cargo del Ministerio Público y luego una eventual de carácter jurisdiccional ante el tribunal con competencia penal. Entonces, si pensamos en la acción como derecho a la tutela judicial, hay que concordar en que el concepto de acción sólo podría ser predicable respecto de la acusación que da origen al juicio oral, pues sólo ahí y no antes estamos en una verdadera instancia jurisdiccional.

Ahora bien, hay que tener presente en el derecho chileno la posibilidad de que la víctima presente una querella ante el juzgado de garantía. Sin embargo, el hecho de presentar la querella no arroja como resultado necesario que se llegue al juicio oral ante el tribunal oral en lo penal, pues el Ministerio Público tiene una serie de facultades conferidas en la Constitución y las leyes que pueden determinar que no se llegue a juicio penal.

Por lo demás, el juzgado de garantía que recibe la querella del ofendido por el delito no es el tribunal que conoce de la pretensión penal. Se trata en lo principal de un tribunal de control de las actuaciones del Ministerio Público y de tutela de los derechos de las personas que participan del procedimiento penal, con especial consideración del imputado.

Todo lo anterior indica que la acción penal es algo completamente diferente de la acción civil ${ }^{34}$. Y si se quiere seguir hablando de acción penal

${ }^{33}$ Véase: Gimeno Sendra, Vicente, Fundamentos de Derecho procesal (Madrid, Civitas, 1981), p. 137

${ }^{34}$ Véase: PÉrez GIL, Julio, La acusación popular (Comares, Granada, 1998), p. 253. 
parece ser que la recomendación es hacerlo en un sentido del todo particular y diferente de su sentido civil ${ }^{35}$.

Si la acción parece ser esencial en el proceso civil, lo que se entronca por lo demás con la garantía del principio "ne procedat iudex ex officio", ya que un juez que actuara de oficio supondría una intromisión intolerable en la esfera de los derechos e intereses de los ciudadanos, en el proceso penal sólo es importante la actuación a petición de parte del juez penal para asegurar de mejor modo su imparcialidad ${ }^{36}$. Por ello es común encontrar opiniones doctrinarias en el sentido que la acción no es indispensable en el proceso penal y podría perfectamente no hablarse de acción penal ${ }^{37}$.

Lo que parece ser esencial al proceso penal es simplemente la eficacia de la represión jurídica de los delitos, por un lado, y la garantía del sujeto pasivo del proceso, por otro. Se puede así prescindir perfectamente del concepto de acción si entendemos en ese término una idea de derecho o potestad. Simplemente se trata de la existencia de garantías de imparcialidad consistentes en que un sujeto distinto del juez acuse a otro ciudadano. Pero en todo ello el término acción está demás.

La acción penal parece ser completamente abstracta, vacía del concepto de derecho subjetivo sustancial y de interés de parte. La acción penal es una simple prolongación del principio de legalidad. Con la acción se activa el proceso penal. Tanto el Ministerio Público como el tribunal cumplen con sus deberes de realizar las prescripciones dispuestas por la norma penal positiva. Ambos, Ministerio Público que ejerce la acción penal y juez que conoce y resuelve la acusación, están vinculados al principio de legalidad ${ }^{38}$.

\section{LA ACCIÓN PENAL COMO DERECHO CONSTITUCIONAL: ANÁLISIS COMPARADO}

En los sistemas procesales penales comparados existen dos grandes modelos referidos a la actuación de los particulares en el proceso penal. Por un lado, y dejando de lado el análisis de aquellos delitos que no comprometen seriamente un interés publico y que se somete a un criterio de oportunidad la incoación o no por parte del ofendido del proceso penal (delitos de acción privada los denomina nuestro Código Procesal Penal en el artículo 55), existen aquellos sistemas que pese a tener un Ministerio Público que persigue los delitos y ejerce la acción penal, confieren también a los ofendidos por delito

\footnotetext{
${ }^{35}$ Véase: Ricci, Gian Franco, cit. (n. 13), p. 135.

${ }^{36}$ Véase: Caianiello, Michele, cit. (n. 28), p. 13.

${ }^{37}$ Véase: Ricci, Gian Franco, cit. (n. 13), p. 143; De la Oliva, Andrés, cit. (n.

${ }^{38}$ Véase: Caianiello, Michele, cit. (n. 28), p. 11.
} 1), p. 117. 
o bien a todo ciudadano el ejercicio de la acción penal. Este es el sistema español que en parte sigue el chileno.

Por otra parte están aquellos sistemas que entienden que la persecución penal es un asunto de interés público por lo que solo atribuyen al Ministerio Público la persecución de los delitos excluyendo en términos generales al ofendido por delito o a todo ciudadano del ejercicio de la acción penal. Este es el caso de Italia.

En el caso español se ha entendido por el Tribunal Constitucional que la acción penal está incluida dentro del derecho a la tutela judicial efectiva reconocido en el artículo 24 CPol.Esp. En este sentido, el ofendido por delito puede siempre ejercer la acción penal porque es un derecho reconocido constitucionalmente a su favor. Y en el caso del actor popular, se ha entendido también por el Tribunal Constitucional español que está incluido en el derecho a la tutela judicial efectiva pero no ya en el artículo 24 sino en el 125 CPol.Esp.

Ha dicho el Tribunal Constitucional español que los ofendidos por delito tienen un interés digno de protección por los tribunales de justicia, interés que consiste en solicitar la actuación del ius puniendi del Estado a fin de obtener la plena vigencia del principio sustantivo de legalidad (sentencia del Tribunal Constitucional español $N^{\circ} 40 / 1994$ de 15 de febrero, que reitera lo ya señalado en la sentencia el mismo tribunal $\left.N^{\circ} 37 / 1993\right)$. Se ha entendido que entre los intereses legítimos a que se refiere el artículo 24.1 CPol.Esp. se halla incluido el interés común en la represión de la criminalidad ${ }^{39}$.

Obviamente la acción popular no implica un reconocimiento para los particulares de un derecho a obtener una condena de otra persona, así como tampoco implica un derecho, ni aun cuando se trata de la parte ofendida, a determinar cómo debe actuar el acusador público ${ }^{40}$.

En el caso chileno, hemos visto que nuestro Tribunal Constitucional también se ha pronunciado en un sentido similar al español, aunque en nuestro país el análisis debe ser centrado en la acción penal del ofendido por delito, no en la acción popular.

En Chile, a diferencia de España, no hay mucha discusión crítica al respecto. Una de esas escasas críticas la expresan María Inés Horvitz y Julián López, quienes afirman que en Chile se ha exagerado con los poderes procesales que tienen las víctimas de delito, avanzando más allá del modelo inspirador, al menos en lo que respecta al poder de la víctima de forzar la acusación, cuando el Ministerio Público decide no acusar al cierre de la investigación, situación que se inspira en la Ordenanza Procesal Penal alemana. Sin embargo, en

\footnotetext{
${ }^{39}$ Véase: DíEz-Picazo, Luis María, cit. (n. 31), p. 155.

${ }^{40}$ Ibíd., p. 156.
} 
Alemania la víctima puede forzar a que el órgano persecutor público acuse, situación distinta a la nuestra donde la víctima puede reemplazar al órgano público en la acusación y en el juicio penal. Se pone atención por estos autores en el peligro de una privatización del derecho penal, con un eventual renacimiento de la pena privada, relativizándose el papel del Estado en el derecho penal y en la aplicación de penas ${ }^{41}$.

En España, De la Oliva ${ }^{42}$ ha sostenido que el artículo 24.1 CPol.Esp. se acomoda mal a la realidad jurisdiccional penal. Piénsese, agrega, que cuando el artículo 24.1 se refiere a la tutela judicial de los derechos e intereses legítimos, no parece haber duda que se hace referencia a derechos e intereses materiales o sustantivos, que en materia penal no son atribuibles a los justiciables.

El único interés que puede estar presente en el proceso penal es posibilitar la solución pacífica del conflicto penal abriendo paso a la actuación jurisdiccional de la ley en el debido proceso, interés que parece no concordar con los referidos en el artículo 24.1 CPol.Esp. ${ }^{43}$.

Por ello es que en España hay críticas al actuar del Tribunal Constitucional y su concepción de la acción penal incluida dentro del derecho fundamental a la tutela judicial efectiva de que habla el artículo 24.1 CPol. Esp. Es que en el proceso penal no hay intereses particulares que tutelar. No hay más interés que el referido a lograr la paz social o, dicho de otro modo, el único interés que busca el proceso penal es el de restablecer la paz jurídica de la comunidad puesta en entredicho por la infracción punitiva y la consiguiente reafirmación de la validez de la norma violada ${ }^{44}$. No existiría un derecho subjetivo público de naturaleza constitucional al ejercicio de la acción penal, ni siquiera para el ofendido o perjudicado por el delito, conducente a la satisfacción de un interés propio al pronunciamiento de una sentencia condenatoria o bien absolutoria ${ }^{45}$.

El único interés que podría tener el ofendido por delito en sede penal, es la necesidad de verdad, o bien derechamente la venganza o la coacción, pero ellos no pueden tener cabida dentro de un derecho de acción, como derecho fundamental.

El reconocimiento de la acción popular penal dentro del derecho a la tutela judicial choca con la idea, inherente al Estado moderno, de que la represión de los delitos debe ser una función pública. A juicio de Luis María Díez-Picazo, la situación española se debe a una errónea interpretación del

${ }^{41}$ Véase: Horvitz, María Inés - López, Julián, cit. (n. 21), pp. 538 ss.

${ }^{42}$ Cfr. De la Oliva, Andrés, cit. (n. 1), p. 142.

${ }^{43}$ Véase: Pérez Gil, Julio, cit. (n. 33), p. 272.

${ }^{44}$ Véase: Pedraz, Ernesto, Derecho procesal penal (Madrid, Colex, 2000, I: Principios de Derecho procesal penal, p. 46.

${ }^{45}$ Véase: PEdRAZ, Ernesto, cit. (n. 43), p. 48. 
derecho inglés. El error consiste en que en Inglaterra existe acción popular para incoar un procedimiento penal, pero la persona que incoa el procedimiento no lo hace a título personal, sino en nombre de la Corona. El actor popular asume una función pública. Pero si la Corona decide actuar por sí misma a través de los órganos predispuestos para ello (General Attorney y Director of Public Prosecutions), toda otra persona queda desplazada de la acusación popular. En definitiva no hay acción popular en Inglaterra, sino un ejercicio difuso de funciones públicas ${ }^{46}$.

España es un caso aislado dentro del contexto europeo, pues la inmensa mayoría de los Estados europeos, a uno y otro lado del Canal de la Mancha, atribuyen la persecución penal, por regla general, exclusivamente a órganos públicos ${ }^{47}$.

En Italia, se pone especial énfasis en que al Ministerio Público le corresponde el ejercicio de la acción penal como un deber inderogable. A su vez, el debido proceso está pensado especialmente respecto del imputado quien tiene un derecho de defensa en sentido lato ${ }^{48}$. La situación en Italia es manifiestamente pública en materia de ejercicio de la acción penal. La persona ofendida por el delito, aun cuando sea titular del bien jurídicamente tutelado por la norma incriminadora y, por tanto, interesada en la determinación de la pretensión penal, se encuentra en una posición subalterna al funcionario del Ministerio Público, respecto del cual tiene en lo fundamental solo poderes de estímulo e impulso ${ }^{49}$.

La víctima de delito tiene reconocido el derecho a intervenir en el procedimiento penal oponiéndose a la solicitud de archivo presentada por el Ministerio Público. Para ello debe ser notificada en la causa. Pero en todo ello no hay derecho a la tutela judicial alguno, sino un derecho de intervención en el procedimiento como expresión del principio del contradictorio ${ }^{50}$.

En Italia, ni siquiera en los delitos de acción privada (delitos contra el honor, contra la libertad sexual, etc.), en que el procedimiento solo se puede iniciar por querella del ofendido, se entiende que se está frente a un ejercicio privado de la acción penal, pues la querella si bien remueve un obstáculo para la incoación del proceso penal, per se no provoca la actuación jurisdic-

${ }^{46}$ Véase: Díez - PiCAzo, Luis María, cit. (n. 31), p. 153.

${ }^{47}$ Véase: Chiavario, Mario, Diritto processuale penale. Profilo istituzionale (4a edición, Torino, Utet Giuridica, 2009), p. 122.

${ }^{48}$ Véase: GREVI, Vittorio, Alla ricerca di un processo penale "giusto". Itinerari e prospettive (Milano, Giuffrè, 2000), p. 5; Comoglio, Luigi Paolo, Etica e tecnica del "giusto processo" (Torino, Giappichelli, 2004), p. 37.

${ }^{49}$ Véase: Normando, Rosalba, $L$ 'esercizio dell 'azione e la richiesta di giudizio nel processo penale (Torino, Giappichelli, 2000), p. 57.

${ }^{50}$ Véase: Ciavola, Agata, Il diritto d'intervento della persona offesa nel procedimento di archiviazione en Cassazione penale, 39 (1999), p. 347. 
cional, porque la marcha del proceso queda exclusivamente en manos del Ministerio Público ${ }^{51}$. En estos casos, el Ministerio Público no actúa porque se lo ha pedido el ofendido por el delito, sino porque la ley le exige actuar en cuanto funcionario público sujeto al principio de legalidad. La querella en estos casos solo sirve como un estímulo para el cumplimiento del deber del órgano estatal ${ }^{52}$.

Más claro aun, Fausto Giunta expresa que la querella, en los delitos de acción privada, no constituye un derecho al procedimiento penal ${ }^{53}$.

En mi concepto, y volviendo a la situación de nuestro país, el reconocimiento que hace el artículo 83 inciso $2^{\circ} \mathrm{CPol}$. al ofendido por delito para ejercer la acción penal, debe ser visto fuera del derecho fundamental de acción o a la tutela judicial, ya que éste sólo se reconoce a los individuos para que puedan pedir tutela a sus derechos subjetivos o intereses legítimos, los que, como se ha visto, es bastante discutible que puedan existir en materia penal. Si han de considerarse derechos fundamentales en materia procesal penal, debe ponerse especial atención en la persona del imputado por delito y no de la víctima.

Lo anterior se condice con el Derecho internacional de los derechos humanos, pues éste garantiza siempre las garantías de un proceso justo para quien es acusado por delito. Así puede verse en el artículo 6.1 de la Convención europea de los derechos del hombre; artículo 14.1 del Pacto internacional de derechos civiles y politicos; artículo 10 de la Declaración universal de los derechos del hombre; artículo 47, 2a línea, de la Carta de los derechos fundamentales de la Unión Europea, y artículo 8.1 de la Convención americana de derechos bumanos. Estas cartas internacionales omiten todo derecho o exigencia sobre quien debe sostener la acusación.

Cosa distinta, en todo caso, es que algunas de esas garantías del debido proceso deban garantizarse al ofendido por delito si es que participa del proceso penal. Ello puede derivarse del contradictorio como principio esencial al proceso.

Ahora bien, si no se puede hablar de un verdadero derecho fundamental de acción que tiene como titulares a los ofendidos por delito, se debe buscar una interpretación al artículo 83 inciso $2{ }^{\circ} \mathrm{CPol}$. La pregunta que corresponde formularse es, pues, ¿qué se quiere decir cuando se expresa que el ofendido por delito podrá ejercer igualmente la acción penal? La respuesta a mi juicio consiste en lo esencial en que el legislador debe permitir a la víctima

${ }^{51}$ Véase: Caianiello, Michele, cit. (n. 28), p. 111.

${ }^{52}$ Véase: Calderano, Biagio, Contributo allo studio del diritto di querela (Padova, Cedam, 1978), p. 53.

${ }^{53}$ Cfr. Giunta, Fausto, Interessi privati e deflazione penale nell 'uso della querela (Milán, Giuffrè, 1993), p. 104. 
por delito una participación en el enjuiciamiento criminal, como pasaré a expresar a continuación. Pero participación en el procedimiento no quiere decir ejercicio del derecho a la tutela judicial.

\section{DERECHO DE LA VÍCTIMA A PARTICIPAR EN EL ENJUICIAMIENTO CRIMINAL: COHERENCIA CON EL PRINCIPIO DE OFICIALIDAD}

Los sistemas procesales penales derivados del sistema francés de enjuiciamiento criminal permiten una amplia participación de la víctima por delito para que en el mismo procedimiento penal puedan obtener una reparación de carácter civil. Chile siguió ese camino con el Código de Procedimiento Penal de 1906 y reitera tal criterio en el Código actual (párrafo $2^{\circ}$ del libro I, título $3^{\circ}$ ).

Sin embargo, desde hace algunos años se observa una evolución que considera los intereses de la víctima en el proceso penal que van más allá de sus intereses privados o civiles. Hoy en día muchos sistemas procesales penales permiten y fomentan la participación de la víctima en la persecución penal para, como sostiene Maier, una mejor solución de caso ${ }^{54}$.

Esa idea de permitir la participación de la víctima en el procedimiento penal para una mejor solución del caso debe llevarnos a no ver en el derecho a la tutela judicial la justificación de su participación, sino que razones de eficacia en la persecución penal. Así se dice que el deseo vindicativo de la víctima puede orientarse en pro de la persecución y castigo de las infracciones punibles, coadyuvando con el Ministerio Público ${ }^{55}$.

Otros autores justifican la participación de la víctima en el enjuiciamiento criminal producto de una crisis del principio de legalidad. Nada asegura que el órgano persecutor estatal cumplirá con objetividad su deber de perseguir los delitos, dejando siempre espacios a la discrecionalidad en la interpretación de la ley. Ello es particularmente relevante en sistemas penales, como el italiano, donde es obligatorio para el órgano persecutor ejercer la acción penal, sin que existan criterios de oportunidad. De este modo, conferir un poder a los particulares para participar en el procedimiento penal constituiría una suerte de control implícito para que el órgano persecutor cumpla con sus deberes constitucionales y legales ${ }^{56}$. Pero aun en sistemas como en chileno donde hay criterios de oportunidad reconocidos por la ley al Ministerio Público, el ofendido por delito puede controlar que el órgano cumpla con lo que

${ }^{54}$ Cfr. Maier, Julio, Derecho procesal penal, I: Fundamentos (2a edición, Buenos Aires, Editores del Puerto, 2004), p. 823.

${ }^{55}$ Véase: Pedraz, Ernesto, cit. (n. 43), p. 48

${ }^{56}$ Véase: Caianiello, Michele, cit. (n. 28), p. 61. 
dispone la ley. La víctima podrá controlar que los poderes discrecionales que le reconoce la ley al Ministerio Público no deriven en arbitrariedad.

Ahora bien, habrá de distinguirse la participación en el procedimiento penal como víctima o como actor popular. En el primer caso el control de la víctima sobre las actuaciones del Ministerio Público puede ser vista como un contrapeso que juega en beneficio del deseo vindicativo de ella, mientras que la participación del actor popular puede tener fines públicos, especialmente cuando el Ministerio Público depende del Ejecutivo, como es el caso de varios países. En este caso, el actor popular controlará que el poder político no obtenga ventajas, tanto por exceso como por defecto, en la acusación, manipulando al órgano acusador.

En todo caso, en uno u otro sistema, la posibilidad de que haya varios acusadores implica, por definición, la posibilidad de controles recíprocos ${ }^{57}$.

La participación de la víctima en el procedimiento penal, por lo tanto, puede ser vista como una instancia que coadyuva en la persecución penal, o bien como un mecanismo de control de las actuaciones del Ministerio Público. Sin embargo, si esa es la justificación para reconocer el derecho de la víctima para participar en el procedimiento penal, tampoco se debe descartar que un adecuado control judicial y administrativo sea la vía para llevar adelante tal finalidad ${ }^{58}$, sin que sea estrictamente necesario encomendar esa función a la víctima del delito.

Sin embargo, la participación de la víctima en el procedimiento penal puede justificarse además por otras razones. Esa razón está dada por una idea del procedimiento penal como instancia compositiva del conflicto que ha generado la conducta antijurídica ${ }^{59}$. Si la víctima puede querellarse y participar activamente de la investigación penal, antes de llegar al juicio penal se puede intentar una composición de la situación con beneficios individuales y sociales

En Chile esta participación de la víctima es bastante amplia. Mauricio Duce y Cristián Riego ${ }^{60}$ sintetizan esta idea señalando que el Código Procesal Penal permite la intervención del querellante en los delitos de acción pública en calidad de acusador adhesivo o particular (artículo 261). Asimismo se contempla un mecanismo de forzamiento de la acusación y de privatización de la acción cuando el fiscal intentare sobreseer un caso (artículo 258 CPP.). Y también se admiten acuerdos reparatorios entre imputado y víctima con

${ }^{57}$ Véase: DíEZ - Picazo, Luis María, cit. (n. 31), p.

${ }^{58}$ Véase: Horvitz, María Inés - López, Julián, cit. (n. 21), p. 296.

${ }^{59}$ Véase: SCALFATI, Adolfo, La vittima del reato nel processo penale cileno en Rivista Italiana di Diritto e Procedura Penale, 47 (2004), p. 881.

${ }^{60}$ Véase: Duce, Mauricio - Riego, Cristián, Proceso penal (Santiago, Editorial Jurídica de Chile, 2007), p. 543. 
el efecto de extinguir la acción penal pública aun contra la voluntad del Ministerio Público (artículo 241 CPP.), entre otros aspectos.

Para nuestro Tribunal Constitucional, en su sentencia rol $N^{\circ} 815-07$, el sistema legal vigente de participación de la víctima en la persecución penal no es satisfactorio, pues la determinación de si se llega a juicio penal es resorte exclusivo del Ministerio Público. En efecto, para poder llegar a la etapa de juicio oral en el procedimiento ordinario, se requiere que previamente se haya acusado o se haya podido forzar la acusación. Pero para llegar a esa etapa se tiene que haber formalizado la investigación. Pero aquí es donde se produce la interrupción de la participación de la víctima en el procedimiento. El artículo 230 CPP. no establece un deber ni plazo para el Ministerio Público de formalizar la acusación, lo que trae como consecuencia que aunque el ofendido hubiera presentado querella y ésta ha sido declarada admisible por el juez de garantía, de nada le sirve haber realizado ese acto porque si no formaliza el Ministerio Público la investigación, no se sigue adelante con el procedimiento. Es decir, teniendo el poder discrecional el Ministerio Público para formalizar o no, en la práctica tiene el monopolio de la acción penal, lo que, a juicio de los sentenciadores, iría en contra de lo que quiso asegurar el artículo 83 inciso $2^{\circ} \mathrm{CPol}$.

Lo que sostiene el Tribunal Constitucional en esta sentencia rol $\mathrm{N}^{\circ} 815$ -07 , es que por aplicación del artículo 83 inciso $2^{\circ} \mathrm{CPol}$., habiendo querella y ésta ha sido declarada admisible por el órgano jurisdiccional, se debe colegir que se tiene un derecho a que el Ministerio Público formalice la investigación para así poder llegar al juicio penal, lo que corresponde como contenido del derecho fundamental de la víctima al proceso o a la tutela judicial. La víctima de delito tendría así un derecho fundamental a la investigación y al juicio penal.

Hoy en día la interpretación que sostiene el Tribunal Constitucional es menos tajante que la posición expresada en el fallo rol $\mathrm{N}^{\circ} 815-07$. En general el Tribunal Constitucional sostiene que la víctima tiene un derecho a la tutela judicial penal, pero ello no conlleva necesariamente a que se tenga un derecho absoluto a que el Ministerio Público investigue y formalice. Desde luego la víctima no puede obligar al Ministerio Público a que formalice la investigación, sino que ello podrá determinarlo el juez de garantía.

En efecto, ha sostenido el Tribunal Constitucional en sentencia de fecha 20 de agosto de 2009, rol 1337-09, que el artículo 186 CPol. permite al querellante, que también puede ser una persona a quien afecte la no formalización judicial de la investigación, pedir al juez de garantía que ordene al fiscal informar acerca de los hechos que fueren objeto de la querella e, incluso, fijarle un plazo para que formalice la investigación (considerando $7^{\circ}$ ).

A su vez, en la sentencia de fecha 3 de noviembre de 2009, rol 1380-09, 
sostiene el Tribunal Constitucional que el artículo $186 \mathrm{CPol}$. da poder al juez de garantía, en tanto responsable de cautelar los derechos de la víctima y querellante, para controlar a solicitud de este interviniente la prerrogativa que otorga el artículo 230 CPP. a los fiscales del Ministerio Público, consistente en determinar la oportunidad de formalizar la investigación (considerando $17^{\circ}$ ). De este modo, sostiene el tribunal que el artículo $186 \mathrm{CPP}$., constitucionalmente interpretado, no admite circunscribir su alcance a la sola tutela del imputado y, de esta manera, es un mecanismo que el legislador ha otorgado al juez de garantía en miras a impedir que la aplicación del inciso $1^{\circ}$ del artículo 230 CPP. confiera al Ministerio Público un monopolio arbitrario del avance del proceso penal que afecte el derecho conferido a la víctima por el artículo 83, inciso $2^{\circ} \mathrm{CPol}$. (considerando $18^{\circ}$ ).

Una idea similar se sostiene en la sentencia de fecha 31 de agosto de 2010, rol $\mathrm{N}^{\circ}$ 1542-09, cuando el Tribunal Constitucional señala que si bien la formalización es un trámite esencial del nuevo proceso penal y su ejercicio responde a una facultad discrecional del Ministerio Público, ésta no puede ser concebida en una dimensión omnímoda que sólo el fiscal pueda decidir si la materializa o no, ya que el propio Código Procesal Penal ha consagrado la posibilidad para el querellante de inducir dicha formalización, cuando posee antecedentes suficientes que la justifiquen, por la vía de solicitar al juez de garantía que le ordene al fiscal informar sobre los hechos que fueren objeto de la investigación y, con el mérito de la misma, incluso fijarle un plazo para que la formalice (artículo 186 del citado cuerpo legal) (considerando $7^{\circ}$ ). Lo mismo se establece en la sentencia de fecha 5 de octubre de 2010 , rol $\mathrm{N}^{\circ}$ 1484-09.

Pero a diferencia de la sentencia rol $\mathrm{N}^{\circ} 815-07$, en las sentencias recién citadas, el querellante no tiene un derecho a la formalización, sino que tiene derecho a pedir al juez de garantía que ordene al Ministerio Público a que formalice la investigación dentro de un determinado plazo. Como sostiene el Tribunal Constitucional en su sentencia rol 1542-09, el querellante tiene la posibilidad de inducir la formalización, pero no obliga directamente al juez de garantía a que ordene al Ministerio Público la formalización ni menos al Ministerio Público a formalizar.

La escasa doctrina que se ha referido a este punto se ha manifestado contraria a la interpretación que el Tribunal Constitucional ha dado del artículo 186 CPP. Así, Guillermo Piedrabuena ${ }^{61}$, apelando a la historia fidedigna del referido artículo 186 , ha señalado que la disposición se estableció con miras a

${ }^{61}$ Cfr. Piedrabuena, Guillermo, Control judicial anterior a la formalización de la investigación (artículo 186 CPP), en Revista de Derecho del Consejo de Defensa del Estado, 23 (junio 2010), pp. 13 ss. 
la protección de los derechos e intereses de los imputados por delito que aun no han sido formalizados. El precepto tendría un claro fin garantista centrado en la persona del imputado, como instrumento que asegura el derecho a ser juzgado dentro de un plazo razonable, sin dilaciones indebidas y que pueda ejercer a cabalidad su derecho de defensa.

Por otra parte, consigna este autor ${ }^{62}$, hay muchos tribunales de justicia que aceptan forzar la acusación sin que exista formalización previa. De esta manera, si terminara por afianzarse esta jurisprudencia, las víctimas podrían pasar directamente al juicio penal ${ }^{63}$, saltándose la decisión de Ministerio Público respecto a formalizar o no.

En otros casos (sentencia de fecha 15 de abril de 2010, rol No 1341-09), el Tribunal Constitucional ha interpretado al artículo 83, inciso segundo CPol., no en el sentido de reconocer al ofendido por el delito un derecho a la investigación ni al proceso penal, es decir, un pleno derecho a la tutela judicial, pues él no se encuentra en la misma situación que el Ministerio Público para ejercer la acción penal, a quien le corresponde primordialmente el ejercicio de dicha acción. En términos muy claros, ha dicho el Tribunal Constitucional que los intereses de la víctima no son vinculantes ni para el fiscal en sus labores investigativas, ni para el juez en sus labores jurisdiccionales, sin perjuicio de que el ordenamiento jurídico le reconozca una serie de derechos (considerando $70^{\circ}$ ). Sostiene esta sentencia que la disposición constitucional (artículo 83 inciso $2^{\circ} \mathrm{CPol}$.) debe ser vista en lo esencial como un mecanismo de control reconocido a la víctima ante posibles arbitrariedades por parte del Ministerio Público. El Código Procesal Penal, sostiene el Tribunal Constitucional en esta sentencia, confiere a la víctima un derecho para reclamar tanto en sede administrativa como judicial de la conducta arbitraria del fiscal.

Dicho lo anterior, corresponde preguntarse por qué el Ministerio Público podría no formalizar la investigación. El argumento más importante dice relación con el poder exclusivo de dirigir la investigación que le reconoce la Constitución a este órgano público (artículo 83 inciso $1^{\circ} \mathrm{CPol}$.). Dentro de

${ }^{62}$ Cfr. Piedrabuena, Guillermo, cit. (n. 63), p. 23.

${ }^{63}$ Para algunos ellos sería inaceptable, pues se sometería a una persona al proceso penal sin una adecuada verificación de la plausibilidad de la hipótesis acusatoria. Para evitar tal situación, se dice, sería necesario imponer al actor el deber de adquisición de un material probatorio adecuado, pero ello trae siempre aparejado un conjunto de problemas referidos al control sobre las formas de adquisición de tal material y a la valoración sobre la idoneidad demostrativa del mismo. Véase: MARZADURi, Enrico, Riflessioni sull 'obbligatorietà dell 'azione penale alla luce della riforma del Codice di Procedura Penale, en Tirelli, Mariella (editora), resenti orientamenti in tema di Pubblico Ministero ed esercizio dell 'azione penale. Atti del convegno Modena, 27 aprile 1996 (Milano, Giuffrè, 1998), p. 47. 
este poder de dirigir la investigación debe entrar a mi juicio la decisión de formalizar o no la investigación, según una opción estratégica para el caso específico $^{64}$.

La pregunta que surge es por qué el legislador reconoce a la víctima el poder de forzar la acusación privatizando absolutamente la persecución penal y no permite asimismo, en términos claros y directos, un forzamiento de la formalización de la investigación.

\section{VIII. ¿QUÚ SE DEBE ENTENDER POR ACCIÓN PENAL?}

Una primera razón para comprender por qué el Código Procesal Penal dispuso el forzamiento de la acusación pero no de la formalización, puede estar dada por una posición del legislador en esta materia, al entender que la acción penal se concreta al momento de acusar, no antes. Y es que, en general, por acción penal en el derecho comparado se entiende la fase de acusación y no de querella o denuncia ${ }^{65}$. No habría, de este modo, exigencia constitucional alguna para darle poderes a la víctima sobre la investigación penal. Por ello la víctima podría forzar la acusación pero no la formalización, pues su derecho constitucional comenzaría al momento de la acusación.

Por lo demás, a esta conclusión se podría llegar interpretando literalmente el artículo 83 inciso $1^{\circ} \mathrm{CPol}$. En efecto, si se examina atentamente este precepto constitucional, se podrá concordar en que de acuerdo al orden en que se establecen los deberes del Ministerio Público, por acción penal habrá de entenderse el poder para llevar a juicio penal al imputado, es decir, en la terminología del Código Procesal Penal, acusar al imputado (artículo 259).

Esto se explica porque el primer deber del Ministerio Público establecido en el precepto constitucional es investigar, y si la investigación se puede iniciar de oficio por este órgano o por denuncia o querella, y luego, si corresponde, el Ministerio Público debe ejercer la acción penal, según reza el artículo 83 inciso $1^{\circ} \mathrm{CPol}$., es lógico concluir que es en este sentido de acusar como se está utilizando la voz acción penal.

De esta misma manera, el Mensaje del Ejecutivo por el que se inició la reforma constitucional que incorporó el Ministerio Público a la primera norma establecía como competencia de este órgano "sustentar la acusación penal ante los tribunales".

Sin embargo, si se observa el Código Procesal Penal, la voz acción penal no parece estar reservada a la acusación. Al respecto el artículo 53 inciso $2^{\circ}$

${ }^{64}$ Véase: Duce, Mauricio - Riego, Cristián, cit. (n. 59), p. 135.

${ }^{65}$ Véase: Gómez Colomer, Juan Luis, El proceso penal alemán. Introducción y normas básicas (Barcelona, Bosch, 1985), p. 76; PÉrez GiL, Julio, cit. (n. 33), p. 267; Horvitz, María Inés - López, Julián, cit. (n. 21), p. 147. 
CPP. da a entender que se refiere al inicio del procedimiento. "La acción penal pública para la persecución de todo delito que no esté sometido a regla especial deberá ser ejercida de oficio por el ministerio público. Podrá ser ejercida además, por las personas que determine la ley”. Esas demás personas son las que pueden denunciar o querellarse. Luego está la situación de los delitos de acción privada cuyo procedimiento sólo puede ser iniciado por la víctima mediante querella (artículo 55 CPP.).

Parece entenderse, por lo tanto, que la expresión acción penal en el Código Procesal Penal se refiere al inicio del procedimiento penal. Pero sucede que la referencia a la acción penal está en el título $3^{\circ}$ del libro I, y el inicio del procedimiento está regulado en el libro II en el párrafo $2^{\circ}$, por lo que la acción penal no se refiere al inicio del procedimiento o no al menos exclusivamente.

La situación, como puede apreciarse, es muy poco clara. No hay una coordinación con lo que se quiere normar entre la Constitución y el Código, ni aun dentro de este último.

¿Cómo ha de entenderse entonces la expresión acción penal? Parece ser que se refiere en el Código a la actividad de persecución de las conductas delictivas, lo que abarcaría todas las actividades necesarias para que se llegue a la sentencia definitiva. De hecho en el Mensaje del Ejecutivo para incorporar a la Constitución al Ministerio Público se hablaba que este órgano tendría "a su cargo la persecución penal pública”, lo que luego en el Senado se modificó por "ejercer la acción penal pública". Acción penal, como se puede apreciar, es algo bastante similar a procedimiento penal y no parece quedar circunscrita a una idea de demanda o acusación.

Si es así como se utiliza la voz acción penal, es decir como el procedimiento para la persecución de los delitos, pues entonces los particulares, del tipo que sean, ofendidos o no por el delito, no podrán ejercer nunca la acción penal, puesto que su ejercicio es un deber del Estado que se realiza a través de los órganos de los que se ha dotado. Sólo el Ministerio Público podría ejercer la acción penal. La víctima sólo podrá iniciar o instar la acción penal o la persecución penal que compete al Estado, pero jamás ejercerla ella.

¿Cómo conciliar entonces la expresión acción penal del artículo 83 CPR con el Código Procesal Penal? Desde luego por acción penal no puede comprenderse en el texto constitucional como se lo hace en el Código del ramo, en el sentido de procedimiento penal, porque como ya se señaló, los ofendidos por el delito jamás podrán ejercerlo.

Una interpretación posible es entender que cuando la Constitución le asegura al ofendido por el delito ejercer igualmente la acción penal, le está garantizando la posibilidad de acusar particularmente junto al Ministerio Público o adherirse a la acusación que deduce el órgano persecutor estatal. Si 
se le reconoce la posibilidad de presentar querella y otros derechos durante la investigación, ello quedaría al criterio del legislador ya que no habría exigencia constitucional al respecto. Pero cuando se sostiene que la Constitución asegura a las víctimas por delito un derecho de acusar, ese derecho aparece condicionado a que la persecución penal esté en un estado tal que esa acusación sea pertinente, lo que determinará el órgano estatal al que le corresponde perseguir los delitos, es decir, el Ministerio Público. Y desde luego, el derecho de acusar no implica asumir autónomamente la calidad de sujeto activo en el juicio penal. Por ello es que sostengo que las víctimas de delito no tienen un derecho de acción o a la tutela judicial, como si de actores civiles se tratase.

En un sistema procesal penal que no es acusatorio puro sino que está basado en el principio de oficialidad y donde la persecución penal es una cuestión de interés público, no pueden las víctimas por delito tener un derecho autónomo a una investigación y a un juicio penal. Podrán colaborar en el enjuiciamiento penal pero no tienen un derecho constitucional a ese enjuiciamiento.

Y todo ello es sin perjuicio de los derechos que les pueda reconocer el legislador a las víctimas de delito, pero se deberá tener como límite el no convertir al proceso penal en un proceso acusatorio puro, es decir como una confrontación de los intereses entre víctima e imputado, pues ello se opone al diseño constitucionalmente predispuesto en el capítulo $7^{\circ} \mathrm{CPol}$. El Código Procesal Penal en algunos aspectos, como en el forzamiento de la acusación y la posibilidad de que la víctima por sí sola sostenga la acusación en el juicio penal, está en el límite del diseño constitucional.

En definitiva, lo que la Constitución exigiría al legislador es que contemple vías para que los ofendidos por delito puedan acusar, sea adhesiva o autónomamente. Otras formas de participación de la víctima en el procedimiento criminal, como presentar querella, pedir diligencias, ser oída, etcétera, quedará a criterio del legislador, sin que existan exigencias constitucionales al respecto.

Entre las razones que podría tener el legislador para contemplar una participación de la víctima en el procedimiento penal, es decir, durante la investigación, está la posibilidad de ejercer controles sobre el órgano persecutor, el aportar antecedentes útiles a la investigación, la posibilidad de lograr soluciones autocompositivas, entre otras.

La activa participación de la víctima en la investigación penal, a mi juicio, debe existir, pero no debe verse en ello ningún tipo de exigencia de carácter constitucional. Es el legislador quien autónomamente determinará si procede darle participación a la víctima durante el procedimiento que dirige el Ministerio Público y cuánta participación. Lo único que la Constitución le 
exige al legislador es que contemple modalidades para que la víctima acuse o pueda participar de la acusación penal. Solo así podemos compatibilizar un proceso penal racional y sujeto al principio de oficialidad, con los intereses de las víctimas de delito.

Pero aun en la acusación particular, no hay que ver en ella un derecho fundamental a la tutela judicial.

\section{BIBLIOGRAFÍA}

Alcalá - Zamora y Castillo, Niceto, Estudios de teoría e historia del proceso (19451972) (México, D.F., UNAM, 1992).

Avsolomovich, Alex - Lührs, Germán - Noguera, Ernesto, Nociones de derecho procesal (Santiago, Editorial Jurídica de Chile, 1965).

BENE, Teresa, La dogmatica dell 'azione penale. Influenza civilistiche ed errori di metodo (Napoli, Jovene, 1997).

BORDALÍ, Andrés, Análisis crítico de la jurisprudencia del Tribunal Constitucional sobre el derecho a la tutela judicial, en Revista Chilena de Derecho, 38 (2011) 2.

Cainniello, Michele, Poteri dei privati nell'esercizio dell 'azione penale (Torino, Giappichelli, 2003).

Calamandrei, Piero, Derecho procesal civil (México, D. F., Editorial Pedagógica Iberoamericana, 1996).

Calderano, Biagio, Contributo allo Studio del diritto di querela (Padova, Cedam, 1978).

Carnelutti, Francesco, Saggio di una teoria integrale dell 'azione, en Rivista di Diritto Processuale, 1 (1946).

Ciavola, Agata, Il diritto d'intervento della persona offesa nel procedimento di archiviazione en Cassazione penale, 39 (1999).

Comoglio, Luigi Paolo, Etica e tecnica del "giusto processo" (Torino, Giappichelli, 2004).

CORDERO, Eduardo, La legitimación activa en el proceso contencioso administrativo, en Ferrada, Juan Carlos (coordinador), La justicia administrativa (Santiago, Lexis Nexis, 2005).

Cordero, Franco, Procedura penale ( $8^{a}$ edición, Milano, Giuffrè, 2066).

Chiavario, Mario, Diritto processuale penale. Profilo istituzionale ( $4^{\mathrm{a}}$ edición, Torino, Utet Giuridica, 2009).

De la Oliva, Andrés, Sobre el derecho a la tutela jurisdiccional. La persona ante la Administración de Justicia: Derechos básicos (Barcelona, Bosch, 1980).

Diez, José Luis, El daño extracontractual. Jurisprudencia y doctrina (Santiago, Editorial Jurídica de Chile, 1997).

Díez-Picazo, Luis María, El poder de acusar. Ministerio Fiscal y constitucionalismo (Barcelona, Ariel, 2000).

Duce, Mauricio - Riego, Cristián, Proceso penal (Santiago, Editorial Jurídica de Chile, 2007).

Floridia, Pietro, Diritti processuali o servizi a favore della vittima? en BISI, Roberta - Faccioli, Patrizia, Con gli occhi della vittima. Approccio interdisciplinare alla vittimologia (Milano, Franco Angeli, 1996).

Gimeno Sendra, Vicente, Fundamentos de derecho procesal (Madrid, Civitas, 1981). 
GiUnta, Fausto, Interessi privati e deflazione penale nell'uso della querela (Milano, Giuffrè, 1993).

Gómez Colomer, Juan Luis, El proceso penal alemán. Introducción y normas básicas (Barcelona, Bosch, 1985).

Grevi, Vittorio, Alla ricerca di un processo penale "giusto". Itinerari eprospettive (Milano, Giuffrè, 2000).

Horvitz, María Inés - López, Julián, Derecho procesal penal chileno. Principios, sujetos procesales, medidas cautelares, etapa de investigación (Santiago, Editorial Jurídica de Chile, 2007).

KUNSEMÜLLER, Carlos, Las actuales relaciones entre derecho penal sustantivo y derecho penal adjetivo, en Romero, Alejandro (coordinador), Estudios de Derecho en homenaje a Raúl Tavolari Oliveros (Santiago, LexisNexis, 2007).

Liebman, Enrico Tulio, $L$ 'azione nella teoria del processo civile, en Rivista di diritto e procedura civile, 4 (1950).

LüDERSSEN, Klaus, Il declino del diritto penale (Milano, Giuffrè, 2005).

MaIER, Julio, Derecho procesalpenal, I: Fundamentos ( $2^{\text {a }}$ edición, Buenos Aires, Editores del Puerto, 2004).

Mandrioli, Crisanto, Corso di Diritto processuale civile (Torino, Giappichelli, 2000).

MARINONi, Luiz Guilherme, Derecho fundamental a la tutela jurisdiccional efectiva (Lima, Palestra, 2007).

Marzaduri, Enrico, Riflessioni sull'obbligatorietà dell 'azione penale alla luce della riforma del Codice di Procedura Penale, en Tirelli, Mariella (editora), Recenti orientamenti in tema di Pubblico Ministero ed esercizio dell 'azione penale. Atti del convegno Modena, 27 aprile 1996 (Milano, Giuffrè, 1998).

Montero Aroca, Juan, La legitimación en el proceso civil (intento de aclarar un concepto que resulta más confuso cuanto más se escribe sobre él) (Madrid, Civitas, 1994).

NogueIra, Humberto, La constitucionalización del proceso: El acceso a la jurisdicción, tutela judicial efectiva o debido proceso, en FerRAda, Juan Carlos (coordinador), La constitucionalización del derecho chileno (Santiago, Editorial Jurídica de Chile, 2003).

Normando, Rosalba, $L$ 'esercizio dell 'azione e la richiesta di giudizio nel processo penale (Torino, Giappichelli, 2000).

Pagliaro, Antonio, Tutela della vittima nel sistema penale delle garanzie en Rivista italiana di diritto e procedura penale, fasc. 1 (enero - marzo 2010).

Pedraz, Ernesto, Derecho Procesal Penal, I: Principios de Derecho procesalpenal (Madrid, Colex, 2000).

PÉrez GiL, Julio, La acusación popular (Granada, Comares, 1998).

Piedrabuena, Guillermo, Control judicial anterior a la formalización de la investigación (artículo 186 CPP), en Revista de Derecho Consejo de Defensa del Estado, 23 (junio 2010).

Piedrabuena, Guillermo, La Constitución y los derechos de la víctima en el nuevo proceso penal chileno, en La víctima y el testigo en la reforma procesal penal (Santiago, Ministerio Público - Editorial Fallos del Mes, 2003).

Ricci, Gian Franco, Principi di Diritto processuale generale (Torino, Giappichelli, 2001).

Romero, Alejandro, Curso de Derecho procesal civil. La acción y la protección de los derechos (Santiago, Editorial Jurídica de Chile, 2006). 
SCAlfati, Adolfo, La fisionomía mutevole della persona offesa nel procedimiento penale dipace, en Diritto penale e processo, 8 (octubre 2002).

Scalfati, Adolfo, La vittima del reato nel processo penale cileno en Rivista italiana di diritto e procedura penale, 47 (2004).

TAREllo, Giovanni, Dottrine del processo civile. Studistorici sulla formazione del diritto processuale civile (Bolonia, Il Mulino, 1989).

Valenzuela, Jonatan, La pena como penitencia secular. Apuntes sobre el sentido de la ejecución de la pena, en Revista de Derecho de la Universidad Austral de Chile, 23 (julio 2010) 1 . 
